\title{
Tolerance Issues in Russian Schools
}

\author{
Evgeny A. Yamburg* \\ State Budgetary Educational Institution of Moscow \\ School No. 109 \\ 20 Akademika Bakuleva Str., Moscow, 117513, Russia
}

Received 21.12.2018, received in revised form 21.01.2019, accepted 04.02.2019

The principal of the well-known Moscow school, Academician of the Russian Academy of Education, reflects on the moral lessons of history, the problem of their educational impact on the modern young generation, the teacher's responsibility for shaping the outlook of schoolchildren, and a true dialogue with them. The purpose of genuine education is moral behaviour, and it is impossible without recognizing a person's personal responsibility for his actions.

Keywords: moral lessons of history, educational influence, duty, historical circumstances, personal experience, ethical standards, reflective judgment, personal meanings.

Research area: pedagogy.

Citation: Yamburg, E.A. (2019). Tolerance issues in Russian schools. J. Sib. Fed. Univ. Humanit. soc. sci., 12(2), 275-284. DOI: 10.17516/1997-1370-0394.

\section{To rise above egoism of personal pain}

A teenager who committed an awful crime at the Kerch College had a shirt with a word HATE written in large letters on it. Hate resulting from what? Resulting from any aspect: social (miserable existence for mother's salary of a nurse), national, confessional; unrequited love, envy of more successful fellow students, etc. Hate for whom? For anyone: picky teachers, a girl who does not love bake, fellow students who make fun of your poor academic success, for the whole unfair and indifferent world.

Hate creates long for revenge in the name of restoring trampled justice. The great goal (obtaining justice) fills your soul with meaningful existence and prompts you to meticulously prepare for the major EVENT, when as a result of an act of bravery, even at the cost of your own life, JUSTICE will be restored. And hundreds of thousands of

(C) Siberian Federal University. All rights reserved

* Corresponding author E-mail address: 109@edu.mos.ru

This work is licensed under a Creative Commons Attribution-NonCommercial 4.0 International License (CC BY-NC 4.0). 
people will find out about you, and you will instantly turn from a mediocre person into a hero of a popular series.

It is not for nothing Sergey Bodrov's character in the "Brother" movie preaches an American after a bloody shoot-out:

"Tell me, American, what is power? Is it money? That's what my brother says. You have a lot of money, so what? I think that power is truth. Whoever has the truth is powerful. So you have deceived someone, made some money. Does it mean you have become more powerful? No, you haven't. Because there is no truth behind you. And the one who was deceived, the truth is behind him, which means he is more powerful. Isn't he? Dmitry Gromov, give me the money."

Thus, the Kerch timid boy, who previously did not stand out among other peers, never had any pathological inclinations, was never involved into criminal stories, had his own poor, flawed truth.

The President of the Russian Federation, who attributes the bloody events in Kerch to the influence of globalism, has his own truth as well. Vladislav Rosliakov actually copied the actions of the killer in the US Columbine High School in 1999. Similar tragedies occur all over the world, and first of all in America, where the opportunity to acquire weapons is many times greater than here. A left-wing idea, based on a thirst for the restoration of justice, wanders victoriously around the planet. Everybody demands justice: Africans, whose income is eight dollars a month, rushing into European countries, Europeans who do not want to spend their budget on feeding newcomers, Americans whose economic and industrial growth has been threatened because transnational corporations are deploying production in Asian countries with cheap work force. Hence the customs wars waged by America. It is really so. But it is important to remember that by stripping America we do not dress ourselves at the same time.

Let us leave aside a huge amount of proposals, mostly of a prohibitive nature (a lot of experts have written enough about their naivety and non-realism); we will only remember that America can be opened, but it is not possible to close it. In this context, America is, of course, a metaphor for globalization.

There is a global cross-cultural crisis. Civilization, figuratively speaking, went out of control. As always, the first who felt this, thanks to the intuition, were the writers in the middle of the past century. The main character of the novel "Citadelle" by Antoine de Saint-Exupéry says: "Life seems to me to be twigs of a scattered broom. And there are not enough divine knots to bind them together." A loss of the sense of integrity of 
the world is extremely painful for both adults and children. Centripetal forces tear apart the consciousness of a modern person. Hence the growth of neuropsychiatric diseases (in Russia this type of diseases came out on top among children and adolescents) and, as a result, the growth of mutual aggression.

The divine knot that must return the lost integrity of being is a support on an unshakable scale of values, which in turn rests on shrines. In other words, a desire to return to antiquity, to the golden age that was in the past. So as a defence against globalism, national and religious clauses are offered. They are designed to save the God-bearing people from a flock of misfits from the Internet worshiping the United States.

But with this approach it is necessary to put an end to the progress that, in the end, brings people a comfortable existence. Hence the blind worship of the progress that will solve all the problems of mankind by automatically increasing technological power. Both approaches are the work of the devil.

At the end of the past century, a philosopher and cultural scientist G. Pomerants wrote remarkably about the losses and acquisitions of the modern civilization: "There are two myths: one is sad, the other is comforting. Both of them lie. The first myth is about the Golden age (and then the Silver Age, the Copper Age, and finally our Iron Age). In the Golden age, old men and sick people are left to be devoured by animals, and extra children are killed. Traces of these customs have survived in the civilizations of the Far East to this day.

The second comforting myth is progress. It is better today than in the dark ages; tomorrow it will be even better. It is difficult to say what will happen tomorrow; maybe nothing will happen. But the world becomes more and more difficult, and a person is getting lost in the wilds of civilization. The more new particulars, the harder it is to grasp a spirit of the whole (and the meaning of life is rooted only in the involvement in the whole). Development is gradually destroying the methods of returning to simplicity and integrity, destroying the symbols of the whole in space with no single fact."

Analysing the Kerch tragedy, the country's leader believes: “...that we all react badly to changing conditions in the world. This means that we do not create the necessary, interesting and useful content for young people." Who would argue? But creation of such content is an incredibly difficult task that eliminates the hysteria and mutual accusations of the so-called fundamentalists and liberals. How and by what means the extreme points of view should be balanced? Such attempts are being made, but for the time being it works out not very well. 
In one of the cities of central Russia, I saw a curious educational institution, the Cossack Information Technology Lyceum. Red stripes on sides of uniform trousers, papakhas and other attributes of the uniform of high school students demonstrated commitment of the administration of the institution to the original traditions. But what does it have to do with the modern information technologies that, as we know, do not have national borders? It turns out that the concept of the lyceum provides for the creation of special Cossack squads to ensure information security on the Internet! No words. Information security is a serious thing. Training of such specialists is in demand by the state; it arouses the interest of those adolescents who do not associate their future with a military career. In addition, the acquired specialization guarantees a decent payment in the future. All this is well-known to the administration of this institution that is concerned about attracting applicants. What's wrong? Instead of a sword that, just in case, hangs on sides of trousers, cadets are encouraged to carry gadgets. A difficult technological problem, being painted in ideological tones, turns into a mission, the essence of which is the search for hidden enemies that dig under the foundation of our special spirituality. So this concept produces conspirology that always generates fear, suspicion and all the same hatred. Which happens inevitably, when trying to connect a body of a bull and a head of a sheep. Such an ideological mutant is not viable.

Conspirological versions of some formidable events spreading very fast throughout the world are the result of a growing mistrust towards the official mass media. As a result of the fear induced by the conspirological versions, the degree of aggression is increasing incredibly. Specialists in history of primitiveness are familiar with the techniques that the ancient tribes used to bring themselves into an aggressive state. Going on the warpath, men of the tribe performed the ritual dance of war. It is characteristic that children, women and old people were hiding in shelters at this time. Why? Because a warrior in the state of combat ecstasy turned into an ideal killing machine that ripped through everything in his path. Whether it was a friend or an enemy - it did not matter. But, returning with victory, men of the tribe performed a special ritual dance of peace, thereby bringing themselves to a normal state. After that the civilian population fearlessly left their shelters. Without knowing it, we are using modern mass media to launch primitive techniques of incredible sublimation of aggression. After this, is it any wonder that a teenager (a seventeen-year-old teenager in a tribe is already a man-warrior who wields a weapon) turns into a killing machine? Therefore, in the Kerch story one should not console oneself with a simple and 
convenient explanation that we are dealing with a psychopath who was not diagnosed in time. Let us ask ourselves a straightforward and uncomfortable question - why is the number of such psychopaths irrevocably increasing?

School does not exist in a vacuum; it exists within seven winds: ideological, geopolitical, socio-economic, national, confessional, psycho-emotional, and, finally, irrational, since human actions are not reducible exclusively to rational motives. Sometimes these winds acquire a squally character bending school with all its inhabitants (teachers, children and parents) from side to side. Obviously, the country needs a long pedagogical therapy, as a result of which we all have to learn the art of dialogue.

While adults have not come to their senses, first of all it is necessary to save children from hatred. In this regard the verses of A. Galich come to mind, whose $100^{\text {th }}$ anniversary we strangely celebrated on the first TV channel in the deep of the night, when children and teenagers sleep soundly. And how wrong it was! In the poem "Kaddish" dedicated to J. Korczak, Galich writes based on his diary:

And I have tried to do all that I could

Not once entreated fate for liberation!

Now I declare, as at extremest unction, If there should be on earth a children's God:

Lord, I have received all things in full, In what department must I make a statement, One thing alone I ask - save me from hatred,

That is one debt that I have not incurred.

A paradoxical fact is that children and adolescents are much more inclined to serious conversations than adults who are worn out with life. Their psyche should not be taken care of by surrounding them with over-care, hiding the tragic pages of the past and the present, based on a patriotic message. This false message was perfectly answered by Gogol in "Theatrical Journey": "Why does he harrow our feelings?" And the other character replies: "These are your feelings, not mine." You need to talk honestly with children. Silent generation loses its history, and therefore the future.

If you give yourself the trouble to think, we are able to create a necessary, useful and interesting content for young people supported by the national leader. Figuratively speaking, we have to move from the endless performance of the ritual "dance of war" 
to gradual mastering of the "dance of peace", thereby bringing the minds and souls of young people to a normal state. This will make the existence of others safer. We must be aware that prohibitive measures designed to reduce the degree of aggression and protect society from bloody incidents are not only ineffective and not fully implemented in the open information space, but also give rise to even greater protest among young people, and therefore, to the same aggression directed at the adult world that is "not catching up."

A heightened thirst for justice that is immanently inherent in adolescents and socially disadvantaged segments of the population inevitably creates a thirst for revenge. But revenge has nothing to do with justice. This idea that is not obvious not only for adolescents, but also for many adults, equally needs proof and specific examples.

G. Pomerants wrote: "Evil is a product of life. Life is always separate, and by asserting itself it strangles and eats other lives. Even trees - by blocking the sun. Animals and birds - even more. And more than others - a person. But a person is not only a living being, he is also a spiritual being, the image and likeness of God, and the awareness of himself as an image of God rises up against the laws of life that he cannot abolish to the end. And yet it aches like conscience. Nobody seems to understand this better than Tiutchev: "And from the earth unto the highest stars unanswered to this very day, a voice lamenting in the wilderness, the soul protests despairingly."

During life, we all inflict wounds on each other experiencing pain and causing it to others. The more valuable are the cases when a person is able to rise above the egoism of his own pain. Such cases are rare, but the more valuable is their presentation to adolescents.

It was 1946. The constituent assembly of the Society for Moral Rearmament gathered in the Swiss Alps. It was initiated by Pastor Frank Buchman. The meeting brought together representatives of many European countries, only Germans were absent. Buchman offered to call them. The others frowned, but invited them. But as soon as the German delegation entered the hall, the French rose and walked out in protest. Its head was a socialist, a member of the Resistance, Irene Laure, whose son was tortured by the Gestapo right in front of her eyes.

Frank Buchman asked her only one question: "How do you, as a socialist, imagine the future of Europe without Germany?" Irene Laure was thinking about it for 36 hours. Then she returned to the hall and took the podium. There was a shrill silence. The Germans shrank expecting angry and humanly justified accusations. Irene Laure 
apologized to the German delegation for not being able to cope with the hatred that gripped her.

The case instantly became known throughout Germany. After that, the German repentance arose, and it was not only on the instructions of the allies. But there is another parallel truth: German average people, who said that not everything was bad because Hitler did many good things, did not get ration cards until they did a forced excursion to one of the concentration camps. The citizens of New Germany who returned in tears were given cards.

In our country, there is not a single person, including the titular nation, who would not have a historical trauma in their hearts. To continue to compare whose pain is more painful is to undermine the foundations of a civic identity.

Overcoming the "egoism of pain" is one of the most important tasks of school courses in national history. This follows an important historical and pedagogical conclusion confirmed in psychotherapeutic practice: any personal or historical trauma is useless and even dangerous to be locked inside by silence. Like delay-action mines, sooner or later they will explode, which we have already witnessed at the turn of the century. People - and first of all the generations entering life - need a deep understanding of the past. At first glance, a deep understanding of the past is the prerogative of professionals. But here, we are not talking about the heartless workshop learning, but about the gradual development of a wise, measured and compassionate attitude of the youth towards history. In this perspective, the problem takes solely pedagogical significance. Its solution requires a long frank conversation on the most sensitive issues. The most difficult thing for a teacher is to take the right tone in such a conversation, to pass between Scylla of hot historicism and Charybdis of cold pessimism. But above all, given the main lessons of the $20^{\text {th }}$ century, a long conversation is necessary so that our children do not turn into executioners like the Kerch teenager.

\section{At first, change yourself (how to extinguish violence in schools)}

A wave of violence that overwhelms schools continues to be the focus of the mass media attention. And it is natural, since the mass media is a mirror designed to reflect the real processes taking place in society. Everything is right, it is impossible to conceal the blatant facts of aggression on the part of teachers towards children and children towards each other, but it is bad when the mirror becomes crooked. Here is what one of the serious administrators responsible for security in schools in one of the Russian 
regions wrote to me in response to the publication in $\mathrm{MK}$ (School formula: provocation + denunciation $=$ meanness. MK dated November 24, 2018):

"On the mass media. They, of course, should put a mirror in front of the system. But it is getting crooked every day. Legends are literally written based on tragic cases. But journalists do not understand that they traumatize the hearts of children, parents and teachers. And this is also a diagnosis. Recently, a murder (quite possibly accidental one) of one schoolboy by another has happened. Parents' and relatives' grief on both sides cannot be measured. It is better if they (reporters) were silent, but not even close! As a result, children with their parents grab voice recorders, video cameras and rush to sell the story "for a thousand roubles." In general, they went crazy for good. I recall a remark made by one character in the film "The Marriage of Balzaminov": Those people are solid who wish themselves good, who go to an insane asylum to ask Ivan Yakovlevich for every little thing. But we do this without any advice."

In our crazy society, we really need to sort things out, and this is the only way we can honestly answer the sacramental Russian question without any evasions and opportunistic political manipulations: who is to blame? Such a courageous approach is primarily a matter of analytical journalism, which seems to be sorely lacking today. As a practical teacher, first of all, I am concerned about another question: what to do?

So what to do in these particular circumstances? In searching for answers to such questions, I trust the artistic intuition of people who genuinely care for the fate of the fatherland. A poet Vladimir Nikolaevich Kornilov is one of them. Shortly before his death, he wrote a poem, the last verse of which I consider as a pedagogical program.

They trade bad for worse

And ownership of the rights,

But all they had to do was

Change themselves first.

Changing yourself is a difficult, but real task.

In fact, neurotic adults, who easily lose temper for any reason, have difficulty mastering other behaviour models that are based on the initial benevolence and the desire to bring joy to another person. The Soviet school struggled with so many manifestations of morals alien to us: long hair (like hippies and Beatles) for boys, make-up and earrings for girls, jeans and Adidas sneakers. We ingloriously lost all 
these wars. And today in a school lobby, I can see an old man with long hair and an earring in his ear (looking like Presniakov senior) and 30-year-old mothers with multicoloured hairstyles waiting for their children. And it makes me smile. As if in addition to the hair colour, we do not have enough reasons for conflict.

Meanwhile, children are extremely observant - they instantly grasp household details capturing the atmosphere of human relations. One of our students went to Canada with her parents. In one of her letters, she tells about the case that struck her.

"So I get into a bus. In the front seat, there was an elderly woman of about eighty years old with a strange appearance. Part of her hair was pink and the other part was blue. Probably the woman wanted to look cool even at her old age! Every new passenger entering the bus gave her a compliment: 'You look charming today! Your hairstyle looks wonderful,' etc. Not a single word of condemnation, not to mention the insults concerning the appearance of the eccentric old woman. Imagine this granny and the reaction of people in the Moscow subway."

Is it easy to be young? No, it is not easy at all. Adolescence is burdened by a huge number of complexes associated with appearance, puberty, etc. Adults forget about it and amuse themselves with myths about a happy childhood. Among those who remembered themselves as adolescents was the world-famous children's writer Astrid Lindgren, the author of "Junior and Karlson" and "Pippi Longstocking".

I am flitting through the pages of recently published book by Sarah Schwardt, "I keep your letters under the mattress," a woman who secretly corresponded with Astrid Lindgren. The correspondence began when Sarah turned only 12 and lasted more than a decade. She was a very difficult teenager: she stole things, she was in a psychiatric clinic, ran away from home, and considered herself ugly, stupid, lazy... And she shared her most secret thoughts with a famous writer. "I have a very bad handwriting," the girl apologizes. In response, Astrid sends her a doctor's prescription written quite indecipherably and advises learning how to type. So the author of "Karlson" removes one of the child's complexes and sets her a new interesting task. Astrid writes to Sarah that at the age of 13 she also considered herself a "freak", gives the girl advice on how to behave in conflict with her classmates. Now it would be called distance education. But the letters are still relevant today... This book, among other things, is an invaluable pedagogical source, and I think that it is equally important for both parents and their children to read it.

Sarah, who became a wonderful grandmother, came to our school the other day and told her story to my students - the girls who suffer from numerous complexes... 
It was a truly magical meeting. A special magnetism emanated from the woman. Its origins are the utmost sincerity in dealing with children, pep and faith in the ultimate victory of good. Is it naive? But there cannot be any other way to deal with children. The conclusion is obvious: a child is able to change himself only with the help of an adult who seeks the same thing.

This is a naive, but effective tool that can and should be used to distinguish aggression in schools.

\title{
Проблемы формирования толерантности в российской школе
}

\author{
Е.А. Ямбург \\ Государственное бюджетное общеобразовательное \\ учреждение города Москвы «Школа № 109» \\ Россия, 117513, Москва, ул. Академика Бакулева, 20
}

\begin{abstract}
Директор известной московской школь академик РАО размышляет о нравственных уроках истории, проблеме их воспитательного воздействия на современное молодое поколение, об ответственности педагога за формирование мировоззрения учеников, об искренности в общении с ними. Цель подлинного воспитания-моральное поведение, и оно невозможно без признания персональной ответственности человека за свои поступки.

Ключевые слова: моральные уроки истории, воспитательное воздействие, долг, исторические обстоятельства, личный опыт, этические нормы, рефлексирующее суждение, личностные смыслы.
\end{abstract}

Научная специильность: 13.00.00 - педагогические науки. 